\title{
Management of wilt and root rot disease of sugarcane in nursery
}

\author{
N.J. DESHMUKH, C.D. DEOKAR AND N.A. MUSMADE* \\ Department of Plant Pathology and Agricultural Microbiology, Mahatma Phule Krishi Vidyapeeth, Rahuri, \\ AHMEDNAGAR (M.S.) INDIA
}

\section{ARITCLE INFO}

Received : 04.06 .2016

Revised : 23.08 .2016

Accepted : 07.09.2016

\section{KEY WORDS :}

Wilt of sugarcane, Rot, Fusarium moniliforme, Pythium gramenicola Biological control, Chemicals management
*Corresponding author:

Email : musmadenarayan@gmail.com

\begin{abstract}
Sugarcane (Saccharum officinarum L.) is one of the most important cash crops cultivated in Maharashtra. Many biotic and abiotic factors limit the sugarcane production. Among the biotic factors fungal diseases are major constraints in reducing the yield of sugarcane. Wilt and root rot diseases of sugarcane are major threat to sugarcane cultivation in Maharashtra. The pure culture of wilt and root rot causing pathogen Fusarium moniliforme. and Pythium gramenicola sp. was successfully isolated from sugarcane wilt and root rot diseases infected samples. Pathogenicity was proved by Koch postulate test was carried out in pot culture under glasshouse conditions by inoculating the soil with pathogenic culture of Fusarium moniliforme and Pythium gramenicola. In vivo management of wilt and biofertilizer and Trichoderma indicated that Fusarium moniliforme and Pythium gramenicola were found in carriers (cocopeat, vermicompost, bagasse, FYM and soil) and the bioagent Trichoderma was proved to be the best antagonists in inhibiting the growth of the fungus. Among these, cocopeat was found most superior and recorded maximum germination percentage, plant height and minimum wilt and root rot disease incidence at 30 and $45 \mathrm{DAP}$ in vivo conditions. it was observed that Blitox and Bavistin inhibited mycelial growth of test fungus at 0.2 per cent concentration and lower disease incidence. It clearly indicated that, these two fungicides are quite effective against the wilt and root rot diseases of sugarcane nursery caused by Fusarium moniliforme and Pythium gramenicola. All the treatments of biofertilizers and Trichoderma were observed to minimize the diseases incidence.
\end{abstract}

How to view point the article : Deshmukh, N.J., Deokar, C.D. and Musmade, N.A. (2016). Management of wilt and root rot disease of sugarcane in nursery. Internat. J. Plant Protec., 9(2) : 489-493, DOI : 10.15740/HAS/IJPP/9.2/489-493. 